
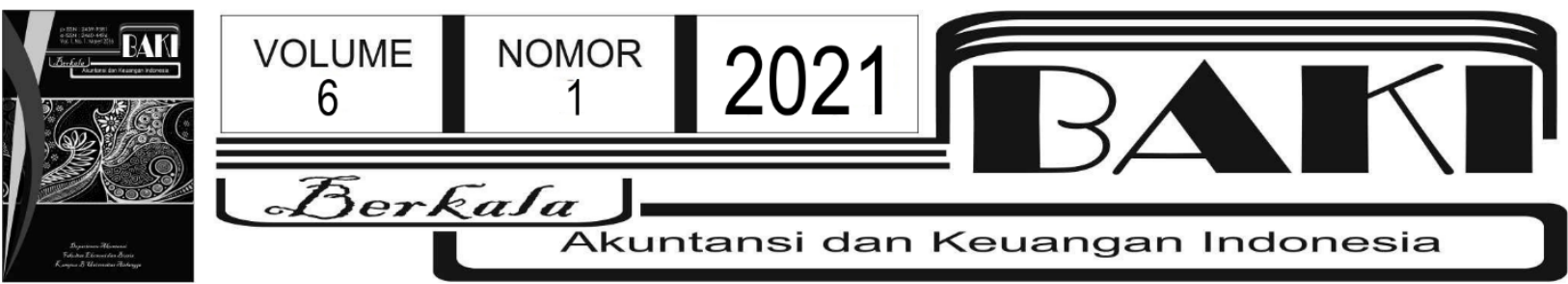

Selling Price Determination Model with Time Driven Activity Based Costing Method at UMKM "Sale Pisang" in Banyuwangi Regency

\title{
Model Penentuan Harga Jual dengan Metode Time Driven Activity Based Costing Pada UMKM "Sale Pisang" di Kabupaten Banyuwangi
}

\section{Deddy Kurniawansyah}

Departemen Akuntansi Fakultas Ekonomi dan Bisnis Universitas Airlangga deddy-kurniawansyah@feb.unair.ac.id

\author{
I NFO ARTIKEL \\ Histori Artikel: \\ Tanggal Masuk 07 Februari 2021 \\ Tanggal Diterima 25 Februari \\ 2021 \\ Revisi Diterima 03 Maret 2021 \\ Tersedia Online 31 Maret 2021 \\ Keywords: \\ Selling Price, Cost of Product, Time \\ Driven Activity Based Costing
}

A B STRAK

The purpose of this study to examine (1) how the stages of the production process for "Sale Pisang Product' that affects the determination of the selling price of Micro, Small, and Medium Enterprises in Banyuwangi? (2) How is the selling price computing model "Banana Sale Products" able to determine a competitive selling price for Micro, Small and Medium Enterprises in Banyuwangi? this Study used survey, qualitative exploratory and action. The analysis data used triangulation method. The results obtained in this studi is the process of computing the production cost of "Sale Pisang Product" still uses a traditional method, so that the resulting product cost is distorted and the selling price becomes uncompetitive. In fact, the product cost compute model using Time Driven Activity Based Costing provides more accurate and informative information for Micro, Small and Medium Enterprises actors in making decisions such as determining the selling price. The Time Driven Activity Based Costing method is able to reduce costs and increase the net income of each "sale pisang" variant. The contribution of this study is expected to create competitive selling price of "Sale Pisang Product" and improve the economic competitiveness of Kab. Banyuwangi is more dynamic based on the potential of natural resources and local wisdom.

\begin{tabular}{l}
\hline Kata Kunci: \\
\hline Harga Jual, Biaya Produk, Time \\
Driven Activity Based Costing
\end{tabular}

Driven Activity Based Costing

\begin{abstract}
A B S T R A CT
Penelitian ini bertujuan untuk menguji (1) Bagaimana tahapan-tahapan proses produksi "Produk Sale Pisang" yang mempengaruhi penentuan harga jual pada Usaha Mikro Kecil dan Menengah di Banyuwangi? (2) Bagaimana model perhitungan harga jual "Produk Sale Pisang" mampu menentukan harga jual yang kompetitif bagi Usaha Mikro Kecil dan Menengah di Banyuwangi? studi ini menggunakan survey, eksploratori kualitatif, dan tindakan. Analisis data menggunakan metode trianggulasi. Hasil penelitian ini menunjukkan bahwa proses perhitungan biaya produksi "Sale Pisang" masih menggunakan metode tradisional, sehingga biaya produk menjadi terdistorsi dan harga jual tidak kompetitif. Padahal, model perhitungan biaya produk menggunakan Time Driven Activity Based Costing menyajikan informasi yang lebih akurat dan informatif bagi para pelaku Usaha Mikro Kecil dan Menengah dalam mengambil keputusan seperti menentukan harga jual. Metode Time Driven Activity Based Costing mampu mengurangi biaya dan meningkatkan laba bersih pada tiap varian produk "Sale Pisang". Kontribusi hasil penelitian ini diharapkan dapat menghasilkan harga jual yang kompetitif dan meningkatkan daya saing ekonomi Kabupaten Banyuwangi yang lebih dinamis berdasarkan potensi sumber daya alam dan kearifan lokal.
\end{abstract}




\section{Pendahuluan}

Perkembangan dunia usaha dan kondisi perekonomian di Kabupaten Banyuwangi saat ini mengalami kemajuan yang sangat pesat, dan dikenal sebagai Kota Wisata (Laporan Kinerja Kabupaten Banyuwangi, 2019). Kondisi ini menjadi tuntutan bagi pengusaha sale pisang yang menjadi salah satu produk unggulan khas Banyuwangi untuk senantiasa tanggap dan proaktif dalam menghadapi persaingan global yang tidak hanya meningkatkan kualitas, dan merek melainkan harus mampu menciptakan harga yang berdaya saing dipasaran. Kaplan dan Porter (2011): Kaplan dan Anderson (2007); Kuchta, dan Troska (2007) menyatakan bahwa untuk menghasilkan harga jual yang unggul diperlukan perhitungan harga pokok produksi yang tepat, sehingga pelaku bisnis dapat mengetahui dengan jelas laba yang dihasilkan.

Fenomena saat ini, pelaku bisnis dalam penentuan harga jual hanya berdasarkan perhitungan kasar atau tradisional. Pelaku bisnis tidak dapat secara pasti menentukan kos per unit produk, dan margin per unit hasil penjualan produknya. Metode perhitungan yang kasar atau tradisional dapat menyebabkan kos per unit produk mengalami distorsi, sehingga pelaku bisnis tidak akan dapat menentukan harga jual yang berdaya saing (Hansen dan Mowen, 2009: Kaplan, dan Porter, 2011: Evaraet dan Werner, 2007; Kuchta dan Troska, 2007). Metode tradisional hanya menggunakan satu macam dasar pembebanan kos untuk pemakaian sumber daya, padahal setiap pemakaian sumber daya yang berbeda dapat saja dikonsumsi berdasarkan dasar pembebanan yang berbeda pula, hal ini menjadi suatu keterbatasan dari metode tradisional. Salah satu strategi yang dapat digunakan untuk menciptakan harga jual produk yang berdaya saing adalah menetapkan cost leadership (Kepemimpinan biaya). Kepemimpinan biaya dapat diperoleh dengan memproduksi produk-produk dengan tingkat biaya yang paling rendah dibandingkan dengan pesaingnya (Thompson, et al, 2010 dan Gervaes, et al, 2010).

Mewujudkan biaya yang rendah, pengusaha dapat meminimalisir biaya pembelian bahan baku dengan meningkatkan hubungan baik dengan pihak vendor, dan efisiensi dalam proses produksi. Efisiensi biaya menjadi faktor yang menentukan dalam memproduksi produk yang biaya rendah. Ketika semua informasi biaya disajikan dengan akurat, maka pengusaha akan dapat mengambil keputusan yang tepat, seperti perhitungan kos produk per unit dan memperoleh harga jual yang tepat dan berdaya saing (Dejnega, 2011).

Penentuan harga pokok produksi yang dapat menghasilkan harga jual yang berdaya saing adalah menggunakan Time Driven Activity Based Costing (TDABC). Metode TDABC lebih mudah diterapkan oleh pelaku usaha baik skala kecil, menengah dan atas di Indonesia, karenakan lebih murah, dan lebih powerful (Soeherman, 2007). TDABC mampu memberikan solusi karena adanya perkiraan waktu yang diperlukan untuk setiap aktivitas sebagai pemicu 
kos yang disebut time driver (Kaplan dan Anderson, 2007: Kaplan, dan Porter, 2011: Stout, dan Joseph, 2011: Godil, et al, 2013).

Hasil empiris yang dilakukan oleh Tjahjadi (2010) menunjukkan bahwa integrasi metode TDABC dan sistem ERP memberikan pengaruh terhadap meningkatnya penghematan biaya, validitas data, kecepatan pengambilan keputusan, kualitas keputusan manajemen, kedalaman data, ketersediaan informasi bagi para manajer operasional, kepercayaan terhadap informasi dan leverage kedua sistem tersebut. Zohreh, dan Samad (2011) dan Kuchta dan Troska (2007), Denovan et al, (2014) membuktikan bahwa harga jual dengan metode TDABC menghasilkan informasi yang bermanfaat dan akurat, diantaranya memperoleh perhitungan biaya lebih akurat, menghitung kapasitas yang tidak memberikan manfaat (unused capacity), dan menjadi strategi perusahaan dalam bulled pricing dan value-based payment.

Naraswari, et al (2014), Higgins, et al (2014), membuktikan yang sama bahwa metode Time Driven Activity Based Costing dapat menghasilkan perbaikan baik jangka pendek dan jangka panjang dalam mengindentifikasi kapasitas maksimal, dan sumber daya yang konsumsinya dapat dilakukan penghematan tanpa menurunkan kualitas produknya. Adeoti dan Valverde (2014) membuktikan bahwa penentuan harga jual jasa dengan menggunakan metode TDABC, pemilik usaha dapat mengetahui kombinasi aktivitas apa saja yang memakan biaya besar, sehingga dapat melakukan pengelolaan biaya dengan baik dan perbaikan yang fokus pada proses, pelanggan, dan produk. Hasil temuan fatkhurrohman (2019) membuktikan bahwa perhitungan metode TDABC pada UMKM "Ngombe Cokelat" menunjukkan detail perhitungan biaya produksi yang lebih tepat sasaran, efisien, dan efektif, dibandingkan dengan metode tradisional yang mengakibatkan adanya distorsi biaya dengan biaya yang telalu tinggi untuk produk es cokelat, churros dan es buah, dan terlalu rendah untuk produk churros ice cream. Azmi (2018) membuktikan bahwa perhituangan metode TDABC untuk perusahaan jasa sangat cocok dan dapat digunakan untuk untuk menentukan biaya layanan per unit aktivitas perawatan kesehatan pada klinik pratama. Meskipun demikian berbeda dengan hasil Namazi (2016) menunjukkan bahwa kemanfaatan TDABC dan penggunaannya yang luas di masa datang sama sekali tidak mendasar, karena TDABC memiliki kelemahan seperti kurangnya kemampuan identifikasi aktivitas pada tahapan implementasi pertama seperti tingkat biaya kapasitas praktis, kesegaraman tingkat kapasitas biaya, penentuan kapisitas tak terpakai, kurangnya akurasi data, dan limitasi pengambilan keputusan manajerial.

Penerapan TDABC telah meluas digunakan untuk berbagai sektor industri dan ukuran usaha, namun penerapan TDABC untuk sektor UMKM masih perlu di kaji lebih mendalam. Penerapan TDABC pada sektor UMKM yang bergerak di makanan khas suatu daerah untuk menentukan model perhtiungan harga jual yang kompetitif, dan dampaknya pada performa 
keuangan yang dilihat dari laba bersih yang diperoleh menjadi keterbaruan penelitian ini. Berbeda dengan penelitian terdahulu yang menerapkan TDABC untuk menghitung biaya produksi produk di sector manufaktur dan biaya pelayanan jasa di sektor jasa dengan ukuran usaha yang relatif besar (Tjahjadi, 2010; Zohreh dan Samad, 2011; Godil dan Yousuf et al.,2013; Azmi, 2018).

Penelitian ini penting dilakukan untuk menunjukkan bahwa ada metode yang lebih baik dalam perhitungan harga jual yang kompetitif dibandingkan metode tradisional sehingga pelaku usaha dapat mengetahui seberapa besar keuntungan yang sebenarnya mereka peroleh. Sektor industri makanan khas daerah menjadi kegiatan UMKM di Kabupaten Banyuwangi. Sale pisang menjadi makanan khas daerah sekaligus menjadi icon buah tangan dari kota banyuwangi. Berbagai macam varian dari sale pisang yang di hasilkan menjadi bentuk inovasi para pelaku usaha. Perkembangan usaha makanan khas ini terus bertambah di kabupaten Banywangi, sehingga menimbulkan persaingan dimana konsumen lebih leluasa dalam berbagai macam produk dan mereka akan menuntut produk yang berkualitas dengan harga yang terjangkau. Mayoritas para pelaku usaha "sale pisang" dalam menentukan harga jualnya masih menggunakan metode kasar atau mengikuti para pesaingnya. Dampak yang dihasilkan dari metode kasar tersebut adalah biaya produksi hanya menitik beratkan pada biaya yang terlibat secara langsung pada proses produksi, sedangkan biaya non-produksi atau biaya tidak langsung di abaikan. Para pelaku usaha baru kebanyakan hanya berusaha mencontoh usaha yang sudah lama berdiri dan mengabaikan bahwa ada setrategi lain yang dapat digunakan untuk menghadapi persaingan, terutama dalam persaingan harga jual seorang pengusaha harus memiliki informasi perhitungan biaya produk yang lebih akurat sehingga dapat mengetahui berapa laba sebenarnya yang akan diperoleh dari usahanya

Penelitian ini ingin mengkaji lebih mendalam dengan mengetahui (1) Bagaimana tahapan proses produksi sale pisang yang berdampak pada penentuan harga jual sale pisang di Banyuwangi? (2) Bagaimana model perhitungan harga produksi sale pisang untuk memperoleh harga jual yang kompetitif bagi UMKM sale pisang di Banyuwangi? Penelitian ini menggunakan triangulation method dengan jenis penelitian survey, exploratory dan action research. Tahapan penelitian ini meliputi dua tahap yaitu pertama, melakukan survei dan kedua, merumuskan model perhitungan harga jual "sale pisang". Metode pengumpulan data menggunakan wawancara dan Forum Group Discussion (FGD). Hasil penelitian ini menunjukkan bahwa model perhitungan harga jual menggunakan Time Driven Activity Based Costing lebih kompetitif dan mampu mengurangi biaya produksi produk serta meningkatkan laba bersih pada tiap varian produk" sale pisang". Diharapkan metode TDABC ini, para pelaku usaha sale pisang dapat menghitung harga jual sale pisang yang lebih akurat, praktis, hemat 
waktu, dan biaya lebih efektif sehingga terwujudnya harga jual yang unggul dan berdaya saing. Kontribusi penelitian ini diharapkan seiring terciptanya harga jual sale pisang yang kompetitif dan sehat akan meningkatkan daya saing ekonomi daerah Kab. Banyuwangi semakin dinamis dan berkualitas yang berbasis pada potensi sumber daya alam dan kearifan lokal. Kontribusi keilmuan hasil penelitian ini adalah meningkatkan literasi ilmu akuntansi manajemen dan biaya dengan memperkuat teori Time Driven Activity Based Costing dalam menurunkan kos produk.

Artikel ini disusun sebagai berikut: bab 1 membahas tentang pendahuluan. Bab 2 membahas tentang tinjauan pustaka, bab 3 membahas metodologi penelitian. Bab 4 membahas hasil penelitian dan bab 5 membahas kesimpulan, keterbatasan, dan saran untuk penelitian selanjutnya.

\section{Tinjauan Pustaka}

\subsection{Sistem Pengendalian Manajemen}

Sistem Pengendalian Manajemen adalah prosedur dan sistem yang formal menggunakan informasi untuk mengelola atau mengubah pola dalam aktivitas organisasi (Hoozee, dan Bruggeman, 2010). Sistem ini mengacu pada serangkaian prosedur dan proses yang digunakan manajer dan semua karyawan organisasi untuk membantu memastikan pencapaian tujuan organisasi mereka. Sistem ini mencakup semua perangkat dan slstem manajer yang digunakan untuk memastikan bahwa perilaku dan keputusan terhadap anggota organisasi konsisten dengan tujuan dan strategi organisasi, namun diluar sistem pendukung keputusan utamanya. Contohnya seperti sistem perencanaan, sistem pelaporan, sistem penganggaran, dan sistem biaya dan pengawasan yang didasarkan pada penggunaan informasi. Dengan demikian, Time Driven Activity Based Costing (TDABC) adalah contoh yang spesifik dalam sistem pengendalian manajemen.

Berdasarkan pengendalian manajemen, informasi akuntansi digunakan sebagai ukuran dimana aktivitas operasional dapat di pantau dan dikendalikan (Hooze, dan Bruggeman, 2010). TDABC menemukan kemungkinan kapasitas yang tidak terpakai, memungkinkan perbaikan operasional, interaksi antara time driver, mendeteksi proses tanpa nilai dan perubahan dalam produksi, pemuatan, pengiriman, penyimpanan dan lain-lian. Oleh karena itu, TDABC menjadi informasi akuntansi dalam sistem pengendalian manajemen yang baik untuk mendesain strategi rantai pasokan kompetitif yang baru, tidak hanya dengan anggota lain dari rantai, tetapi juga antara divisi perusahaan tertentu dan sebagai instrumen untuk mengidentifikasi profitabilitas pelanggan perusahaan dan peluang pasar baru. 


\subsection{Revolusi sistem biaya}

Tujuan dari sistem biaya adalah membuat estimasi yang akurat terhadap biaya produk dari objek biaya yang berbeda-beda (pelanggan dan produk) untuk memberikan informasi yang relevan kepada manajemen dalam membuat keputusan, untuk meningkatkan proses bisnis dan untuk mengelola departemen (Kaplan, dan Porter, 2011).

\subsubsection{Sistem Akuntansi Biaya Tradisional}

Akuntansi biaya tradisional adalah biaya yang di desain untuk perusahaan manufaktur dan berorientasi ke penentuan kos produk dengan fokus biaya pada tahap produksi (Kaplan, dan Porter, 2011). Keterbatasan sistem akuntansi biaya tradisional Menurut Kaplan, dan Porter (2011) adalah sistem akuntansi biaya tradisional dapat membuat biaya menjadi terdistorsi sehingga informasi yang dihasilkan menjadi tidak akurat, dan manajemen mengambil keputusan menjadi tidak tepat, karena (a) Penggunaan jam kerja langsung satu-satunya alat untuk dasar alokasi biaya overhead pada produk, (b) Marjin laba sulit dijelaskan, (c) Titik fokus pada proses produksi, tidak termasuk desain dan distribusi, (d) Biaya fase desain dan distribusi masuk pada biaya periode.

\subsubsection{Activity Based Costing System}

Activity Based Costing System (ABC) adalah sistem informasi biaya yang berorientasi pada penyediaan informasi lengkap tentang aktivitas untuk memungkinkan personel perusahaan melakukan pengelolaan terhadap aktivitas (Kaplan, dan Porter, 2011). Penerapan sistem ABC memiliki banyak keuntungan, namun masih memiliki kelemahan seperti seluruh biaya tidak mudah dibebankan kepada objek biaya. Biaya- biaya yang dikelompokkan dalam sustaining level ketika dialokasikan sering kali juga menggunakan dasar yang bersifat arbiter. Misalnya, biaya keamanan pabrik merupakan contoh dari sustaining level, ketika membebankan hal tersebut pada objek biaya yang berupa produk, maka mungkin digunakan pendekatan arbiter, seperti berdasarkan jumlah jam kerja tenaga kerja dengan alasan semakin lama proses produksi maka membutuhkan jasa keamanan yang semakin besar

\subsubsection{Time Driven Activity Based Costing}

Time Driven Activity Based Costing (TDABC) merupakan metode baru yang menggunakan waktu (time) sebagai pemicu biaya utama, dan TDABC memungkinkan manajemen membebankan resource cots langsung kepada cost object (Tjahjadi, 2010 dan Kaplan, dan Anderson, 2007). Menurut Hon dan Chu (2012) mengungkapkan bahwa 
Terobosan dari TDABC terletak pada estimasi waktu. Waktu pelaksanaan aktivitas diperkirakan untuk setiap kasus aktivitas tertentu, berdasarkan karakteristik yang berbeda dari kasus tertentu. Karakteristik ini disebut "Time-Drivers" karena "driver/pemicu" waktu, yang dihabiskan pada aktivitas tertentu. Model persamaan waktu adalah time driver, memicu waktu yang digunakan dalam aktivitas.

Di lingkungan yang kompleks dimana waktu yang dibutuhkan untuk melakukan aktivitas yang didorong oleh banyak pemicu, TDABC dapat mencakup beberapa pemicu untuk setiap aktivitas (Kaplan, dan Anderson, 2007). TDABC mengeliminasi tahapan-tahapan pendefinisian setiap aktivitas dan dengan sendirinya mengeliminasi kebutuhan untuk membebankan resource costs pada aktivitas. TDABC dikatakan metode yang lebih sederhana, cepat, dan murah karena tidak perlu melakukan aktivitas survey dan wawancara karyawan yang mahal, makan waktu, dan subyektif. Metode ini juga diyakini dapat diterapkan pada sektor UMKM.

\subsubsection{Parameter Time Driven Activity Based Costing}

Menurut Tjahjadi (2010), metode Time Driven Activity Based Costing memiliki dua parameter yaitu: (1) Pembebanan biaya untuk setiap unit waktu yang digunakan sumber daya yang tersedia dalam memenuhi kapasitas tersedia sesuai dengan aktivitas perusahaan. (Total pengeluaran Overhead dibagi dengan total jam kerja karyawan yang digunakan/tersedia). (2) Penilaian dari unit waktu yang digunakan dalam setiap aktivitas : berapa banyak waktu yang digunakan dalam menyelesaikan satu unit produk/barang dalam proses pada setiap aktivitas (hal ini didasarkan pada hasil perkiraan atau pengamatan langsung).

\section{Metodologi Penelitian}

Penelitian ini merupakan jenis penelitian survey, exploratory dan action research yang dilaksanakan di Kabupaten Banyuwangi dengan menggunakan triangulation method. Tahapan penelitian yang dilakukan meliputi dua tahap. Tahap pertama (1 bulan) melakukan studi lapangan/survei digunakan untuk menemukan mengungkap, mengurai permasalahan penentuan harga jual "sale pisang". Tahap kedua (2 bulan) merumuskan model perhitungan harga jual berdasarkan Time Driven Activity Based Costing (TDABC) yang sesuai dengan karakteristik UMKM "sale pisang". Selanjutnya mengaplikasikan harga jual berdasarkan Time Driven Activity Based Costing (TDABC) pada UMKM "sale pisang". Jenis data yang digunakan dalam penelitian ini data primer dan sekunder. Data primer berupa persepsi/pendapat responden terhadap proses produksi sampai penentuan harga jual. Data sekunder berupa data perkembangan UMKM "sale pisang", dan catatan transaksi keuangan. Data primer yang berupa 
persepsi/pendapat tentang proses produksi sampai penentuan harga jual "sale pisang" diperoleh dari pelaku usaha. Data sekunder diperoleh dari sumber dokumen pelaku usaha.

Cara atau metode pengumpulan data yang digunakan dalam penelitian ini adalah sebagai berikut:

\section{Wawancara (interview)}

Wawancara dilakukan kepada persepsi/pendapat tentang proses produksi, penentuan harga harga jual "sale pisang" yang diperoleh dari pemilik usaha, dan karyawan bagian produksi. Metode ini dapat memperkaya informasi yang tidak tertuang dalam dokumentasi / dokumen, namun memiliki kelemahan diantaranya bias subyektif karena perspektif orang tertentu dan juga sulit mengklarifikasi pendapat satu narasumber dengan narasumber lainnya bila terjadi perbedaan penilaian.

Focus Group Discussion (FGD)

Focus Group Discussion (FGD) merupakan metode yang pengumpulan data sekaligus pemecahan masalah-masalah yang diangkat dalam penelitian yang akan dicarikan solusi pemecahan masalah secara kelompok mengacu pada fakta yang ada dengan melibatkan pihak stakeholder seperti pemilik usaha, karyawan bagian produksi, dan keuangan, dan para pakar/ahli seperti tenaga pengajar yang expert dibidang akuntansi manajemen dan biaya. Para pakar/ahli berfungsi sebagai pemateri untuk menyampaikan materi dasar dari konsep perhitungan harga jual menggunakan Time Driven Activity Based Costing (TDABC). Selain itu sebagai tempat konsultatif bagi para pelaku usaha yang butuh pendampingan dalam menghitung harga jual dengan menggunakan Time Driven Activity Based Costing (TDABC).

Data yang berhasil dikumpulkan akan dianalisis secara deskriptif-exploratori kualitatif. Pendekatan kualitatif deskriptif - exploratori digunakan untuk menggambarkan, menjelaskan permasalahan penentuan harga jual sale pisang dan merumuskan model perhitungan harga jual sale pisang sesuai dengan permasalahan dan karakteristik UMKM yang memproduksi sale pisang. Data diperoleh, dikumpulkan dan di analisis dengan pendekatan focus group discussion dimana prosesnya sangat partisipatif dengan melibatkan UMKM yang memproduksi sale pisang. Data yang dianalis dilakukan uji validitas dan reliabilitas dengan cara triangulasi dimana data yang bersumber dari dokumen dan hasil wawancara dilakukan konfirmasi satu sama lainnya. Diharapkan dengan cara ini hasil analisis mencerminkan kondisi, permasalahan dan fakta yang sesuai sehingga diharapkan dapat tersusun model perhitungan harga jual "sale pisang" berbasis TDABC yang kompetitif. Model yang tersusun harus diuji dengan cara menerapkan model tersebut sehingga UMKM "sale pisang" mampu menyusun dan menghitung harga jual secara benar dan tepat. 


\section{Analisis dan Pembahasan}

\subsection{Proses Produksi Sale Pisang}

Berdasarkan hasil survey dan wawancara menunjukkan bahwa proses produksi sale pisang antara pelaku usaha satu dengan yang lainnya adalah sama. Mayoritas pelaku usaha menghasilkan 2 (dua) varian sale pisang, yaitu: (a) Sale Pisang Basah, dan (b) Sale Pisang Goreng. Proses produksi sale pisang basah dimulai dari pengupasan, penjemuran, penyortiran, pengovenan, dan pengemasan. Langkah awal adalah pengupasan. Pada proses ini, pelaku usaha lebih memilih pisang ambon dari pada pisang barlin karena kualitas dan cita rasanya sangat enak dan lebih disukai konsumen. Langkah kedua adalah penjemuran, pisang dijemur selama 5 (lima) Jam sampai kering. Langkah ketiga adalah penyortiran, setelah kering pisang disortir dan dipotong sesuai kriteria, pisang yang kualitasnya tidak baik tidak dilanjutkan ke proses produksi selanjutnya. Langkah ke empat adalah proses pengovenan, pisang yang sesuai kriteria di beri madu, dan perasa (bahan baku penolong), dan dimasukkan ke dalam oven selama 3 Jam. Langkah ke enam adalah pengemasan, sale yang sudah matang akan di packaging dengan baik. Sale pisang basah lebih manis dan tahan lama (kadaluwarsa).

Proses produksi sale pisang goreng dimulai dari pengupasan, penjemuran, penyortiran, pengadonan, penggorengan, dan pengemasan. Langkah awal adalah pengupasan. Pada proses ini, pelaku usaha memilih pisang ambon dan dikupas. Langkah kedua adalah penjemuran, pisang yang matang dengan sempurna atau dalam istilah bahasa jawa "Ndalu" di jemur selama 5 (lima) Jam sampai kering. Pisang yang belum matang dengan sempurna akan di beri obat selama kurang lebih 2 hari sebelum di jemur. Langkah ketiga adalah penyortiran, memisahkan pisang yang siap di goreng dan pisang yang masih perlu dilakukan penjemuran lagi keesokan harinya. Langkah ke empat adalah proses pengadonan, pisang yang telah disortir akan dicampur dengan bahan-bahan lainnya. Langkah ke lima adalah penggorengan. Proses penggorengan membutuhkan bahan penolong seperti tepung beras, gula, garam, minyak, dan air. Langkah ke enam adalah pengemasan. Pisang yang sudah digoreng kemudian ditiriskan dan dikemas. Pada proses pengemasan, membutuhkan bahan penolong yaitu plastik, stiker, dan alat pengepres plastik

\subsection{Proses Penentuan Harga Pokok Produksi Sale pisang}

Rata-rata pelaku usaha (UMKM) sale pisang mampu memproduksi sebanyak 420 unit per hari. 420 unit terdiri dari sale pisang basah sebanyak 400 unit dan sale pisang basah sebanyak 20 unit. Informasi komponen biaya-biaya produksi untuk sale pisang basah disajikan pada tabel 4.1, 4.2, dan 4.3. 
Tabel 4.1. Komponen Biaya Bahan Baku Per Hari Sale Pisang Basah

\begin{tabular}{c|c|c|c|}
\hline Bahan Baku & Jumlah Sisir & \multicolumn{1}{c}{ Harga Per Sisir } & \multicolumn{1}{c|}{ Total Biaya Per Hari } \\
\hline Pisang & 500 Sisir & Rp. 5.000 & Rp.2.500.000 \\
\hline
\end{tabular}

Sumber: Data Primer

Berdasarkan tabel 4.1 menunjukkan bahwa biaya bahan baku lansgung dihitung berdasarkan aktivitas normal harga pasar pisang yang biasa terjadi. biaya bahan baku pisang sebesar Rp. 2.500.000,- (500 sisir pisang @ harga pisang sebesar Rp. 5.000,-) untuk sekali pembelian. Biaya bahan baku adalah biaya utama yang dibebankan langsung untuk menghasilkan sale pisang basah.

Tabel 4.2. Komponen Biaya Tenaga Kerja Langsung Per Hari Sale Pisang Basah

\begin{tabular}{|c|c|c|c|}
\hline Aktivitas Produksi & Jumlah TKL & Upah Per Hari & Total Biaya Per Hari \\
\hline Pengupasan & \multirow{5}{*}{4 Orang } & \multirow{4}{*}{ Rp.30.000,- } & \multirow{4}{*}{ Rp.120.000,- } \\
\hline Penjemuran & & & \\
\hline Penyortiran & & & \\
\hline Pengovenan & & & \\
\hline Pengemasan & & Rp.7.500,- & Rp.30.000,- \\
\hline
\end{tabular}

Sumber: Data Primer

Berdasarkan tabel 4.2 Biaya tenaga kerja langsung adalah biaya tenaga kerja yang berkaitan dengan proses pembuatan sale pisang bisah secara langsung seperti pengupasan pisang, penjemuran, penyortiran, pengovenan dan pengemasan.

Tabel 4.3. Komponen Biaya Overhead

\begin{tabular}{|c|c|c|c|}
\hline Jenis Biaya & Kuantitas Estimasi & $\begin{array}{c}\text { Harga } \\
\text { Estimasi }\end{array}$ & $\begin{array}{c}\text { Jumlah Biaya } \\
\text { Per Hari }\end{array}$ \\
\hline \multicolumn{4}{|l|}{ BBB tak langsung (Bahan Penolong) } \\
\hline Madu & $2 \mathrm{Kg}$ & Rp.115.000 & Rp.230.000 \\
\hline Perasa & 1 Unit & Rp. 24.000 & Rp.24.000 \\
\hline Stiker & 5 Gulung & Rp.19.000 & Rp.95.000 \\
\hline Plastik & 10 Gulung & Rp.15.000 & Rp.150.000 \\
\hline \multicolumn{4}{|l|}{ BTK tidak langsung: } \\
\hline Pengawas (Mandor) & 1 Orang & Rp.20.000 & Rp.20.000 \\
\hline \multicolumn{4}{|l|}{ Biaya Listrik } \\
\hline Penerangan & 1 Unit Lampu (5 watt) & Rp.2.000 & Rp.2.000 \\
\hline \multicolumn{4}{|l|}{ Biaya Gas } \\
\hline $3 \mathrm{Kg}$ & $1,5 \mathrm{Kg}$ & Rp.5.000 & Rp.7.500 \\
\hline Total Biaya Overhead & & & Rp.528.500 \\
\hline
\end{tabular}

Berdasarkan tabel 4.3 Biaya overhead adalah seluruh biaya yang dikeluarkan untuk menyediakan kapasistas sumber daya, selain biaya bahan baku, dan tenaga kerja langsung. 
Biaya yang dialokasikan ke Biaya overhead oleh pengusaha sale pisang seperti biaya bahan baku penolong (madu, perasa, stiker, Plastik), biaya tenaga kerja tidak langsung (pengawas), Biaya listrik (penerangan), dan Biaya Gas elpiji (3kg). Informasi komponen biaya-biaya produksi untuk sale pisang goreng disajikan pada tabel 4.4, 4.5, dan 4.6.

Tabel 4.4. Komponen Biaya Bahan Baku Per Hari Sale Pisang Goreng

\begin{tabular}{c|c|c|c|}
\hline Bahan Baku & Jumlah Sisir & \multicolumn{1}{c|}{ Harga Per Sisir } & \multicolumn{1}{c|}{ Total Biaya Per Hari } \\
\hline Pisang & 40 Sisir & Rp.5.000 & Rp.200.000 \\
\hline
\end{tabular}

Sumber: Data Primer

Berdasarkan tabel 4.4 menunjukkan bahwa biaya bahan baku lansgung dihitung berdasarkan aktivitas normal harga pasar pisang yang biasa terjadi. biaya bahan baku pisang sebesar Rp. 200.000,- (40 sisir pisang @ harga pisang sebesar Rp. 5.000,- ) untuk sekali pembelian. Biaya bahan baku adalah biaya utama yang dibebankan langsung untuk menghasilkan sale pisang basah.

Tabel 4.5. Komponen Biaya Tenaga Kerja Langsung Per Hari Sale Pisang Goreng

\begin{tabular}{|c|c|c|c|}
\hline Aktivitas Produksi & Jumlah TKL & Upah Per Hari & Total Biaya Per Hari \\
\hline Pengupasan & \multirow{5}{*}{2 Orang } & \multirow{6}{*}{ Rp.35.000,- } & \multirow{5}{*}{ Rp.70.000,- } \\
\hline Penjemuran & & & \\
\hline Penyortiran & & & \\
\hline Penggorengan & & & \\
\hline Pengemasan & & & \\
\hline \multicolumn{2}{|c|}{ Total Biaya Tenaga Kerja Langsung } & & Rp. 70.000,- \\
\hline
\end{tabular}

Sumber: Data Primer

Berdasarkan tabel 4.5 Biaya tenaga kerja langsung adalah biaya tenaga kerja yang berkaitan dengan proses pembuatan sale pisang goreng secara langsung seperti pengupasan pisang, penjemuran, penyortiran, penggorengan dan pengemasan.

Tabel 4.6. Komponen Biaya Overhead

\begin{tabular}{|c|c|c|c|}
\hline Jenis Biaya & Kuantitas Estimasi & $\begin{array}{c}\text { Harga } \\
\text { Estimasi }\end{array}$ & $\begin{array}{l}\text { Jumlah Biaya } \\
\text { Per Hari }\end{array}$ \\
\hline \multicolumn{4}{|l|}{ BBB tak langsung (Bahan Penolong) } \\
\hline Tepung Beras & $1 / 2 \mathrm{Kg}$ & Rp.6.000 & Rp.230.000 \\
\hline Gula & & Rp.500 & Rp.500 \\
\hline Garam & & Rp.500 & Rp.500 \\
\hline Minyak Goreng & $1 \mathrm{Kg}$ & Rp.12.500 & Rp.25.000 \\
\hline Stiker & 1 Wadah & Rp.4.000 & Rp.4.000 \\
\hline Plastik & 2 Wadah & Rp. 10.000 & Rp.20.000 \\
\hline \multicolumn{4}{|l|}{ BTK tidak langsung : } \\
\hline Pengawas (Mandor) & 1 Orang & Rp.20.000 & Rp.20.000 \\
\hline Biaya Listrik & & & \\
\hline
\end{tabular}




\begin{tabular}{l|c|c|c}
\hline Penerangan & 1 Unit Lampu (5 watt) & Rp.2.000 & Rp.2.000 \\
\hline Biaya Gas & & & \\
\hline $3 \mathrm{Kg}$ & $1,5 \mathrm{Kg}$ & $\mathrm{Rp} .5 .000$ & $\mathrm{Rp} .7 .500$ \\
\hline Total Biaya Overhead & & & $\mathbf{R p . 8 2 . 5 0 0}$ \\
\hline
\end{tabular}

Sumber: Data Primer

Berdasarkan tabel 4.6 Biaya overhead adalah seluruh biaya yang dikeluarkan untuk menyediakan kapasistas sumber daya, selain biaya bahan baku, dan tenaga kerja langsung. Biaya yang dialokasikan ke Biaya overhead oleh pengusaha sale pisang seperti biaya bahan baku penolong (Tepung Beras, Gula, Garam, Minyak Goreng, Stiker, dan Plastik), biaya tenaga kerja tidak langsung (pengawas), Biaya listrik (penerangan), dan Biaya Gas elpiji (3kg).

\subsection{Perhitungan Harga Pokok Produk Sale Pisang}

Berdasarkan proses produksi, masing-masing varian sale pisang diketahui perhitungan harga pokok produksinya. Tabel 4.7 menunjukkan harga pokok produk per unit masing-masing sale pisang.

Tabel 4.7. Harga Pokok Produk Per Hari

\begin{tabular}{c|c|c}
\multicolumn{1}{c}{ Tipe } & Sale Pisang Basah & \multicolumn{1}{c}{ Sale Pisang Goreng } \\
Biaya Bahan Baku & Rp.2.500.000,- & Rp.200.000,- \\
\hline Biaya Tenaga Kerja Langsung & Rp.150.000,- & Rp.70.000,- \\
\hline Biaya Overhead & Rp.528.000,- & Rp.82.500,-- \\
\hline Total Harga Pokok Produk & Rp.3.178.000,- & Rp.352.500,- \\
\hline Unit Produk & 400 Unit & 20 Unit \\
\hline Harga Pokok Produk Per Unit & Rp.7.900,- & Rp.17.600,- \\
\hline
\end{tabular}

Sumber: Data Primer

Komponen biaya overhead yang dialokasi ke masing-masing produk hanya didasarkan pada estimasi, karena kesulitan untuk mengukur dan mengindetifikasi secara tepat, seperti alokasi biaya listrik. Hal ini membuat biaya yang dialokasikan didasarkan pada estimasi dan mudah dimengerti oleh para pengusaha sale pisang. Pernyatan Bapak Nanang sebagai pengusaha sale pisang basah mengatakan bahwa

"Saya tidak memperhitungkan biaya listrik, karena kebutuhannya tidak telalu banyak. Biaya transportasi, kadang - kadang bersamaan dengan antar dan jemput anak sekolah, sehingga bikin tambah rumit jika saya menghitung biaya-biaya yang kecil seperti itu. (Wawancara 5 Agustus 2019). 
4.4 Penerapan Time Driven Activity Based Costing (TDABC) pada proses produksi dan harga jual UMKM Sale Pisang

Menerapkan Time Driven Activity Based Costing (TDABC) dalam perihitungan harga jual peneliti harus mampu mengetahui seluruh aktivitas dan biaya yang terjadi pada saat proses produksi sale pisang. Time Driven Activity Based Costing menggunakan persamaan waktu (time equation) yang diperoleh dari hasi pemetaan proses bisnis. TDABC secara langsung dapat membebankan resource costs kepada aktivitas-aktivitas dan transaksi-transaksi yang dilakukan. Pembebanan langsung, TDABC hanya memerlukan 2 (dua) parameter yaitu: (1) tariff biaya kapasitas di departemen tertentu (capacity cost rate), dan (2) penggunaan kapasitas oleh setiap transaksi yang dilakukan di departemen tertentu (capacity usage by each trasanction). Analisis konsumsi waktu, aktivitas dikelompokkan menjadi 2 aktivitas yaitu:

Aktivitas pembuatan Sale Pisang Basah:

\section{Pengupasan:}

Pisang yang sudah masak akan dikupas dan dipotong sesuai ukuran yang diinginkan pemilik / sesuai kriteria yang telah ditentukan. Waktu yang dibutuhkan adalah 30 menit.

\section{Penjemuran:}

Pisang yang telah dikupas dijemur dibawah terik matahari sampai benar - benar kering. Waktu yang dibutuhkan adalah 5 jam.

\section{Penyortiran:}

Setelah proses penjemuran, pisang disortir sesuai kriteria yang sudah ditentukan, sekaligus dilakukan pemotongan dengan ukuran yang sama. Waktu yang dibutuhkan adalah 20 menit.

\section{Pengovenan:}

Agar pisang yang dihasilkan berkualitas lebih bagus dngan tekstur yang diinginkan, maka dilakukan pengovenan unutk mencapai tingkat kekeringan pada pisang. Waktu yang dibutuhkan 1 jam, 20 menit.

\section{Pengemasan:}

Sale pisang dikemas sesuai packaging kemasan dan berat yang ditentukan. Waktu yang dibutuhkan adalah 30 menit.

Aktivitas Pembuatan Sale Pisang Goreng: 


\section{Pengupasan:}

Pisang yang sudah masak akan dikupas dan dipotong sesuai ukuran yang diinginkan pemilik / sesuai kriteria yang telah ditentukan. Waktu yang dibutuhkan adalah 10 menit.

\section{Penjemuran:}

Pisang yang telah dikupas dijemur dibawah terik matahari sampai benar - benar kering. Waktu yang dibutuhkan adalah 4 jam.

\section{Penyortiran:}

Setelah proses penjemuran, pisang disortir sesuai kriteria yang sudah ditentukan, sekaligus dilakukan pemotongan dengan ukuran yang sama. Waktu yang dibutuhkan adalah 10 menit.

\section{Pengadonan:}

Sale pisang dilapisi dengan adonan dari tepung dan beberapa bumbu pelengkap. Waktu yang dibutuhkan adalah 10 menit.

\section{Penggorengan:}

Setelah itu sale yang telah dilapisi dengan adonan digoreng hingga kering. Waktu yang dibutuhkan adalah 15 menit.

\section{Pengemasan:}

Sale pisang goreng dikemas dengan packaging dan berat yang telah ditentukan. Waktu yang dibutuhkan adalah 15 menit.

\subsection{Penghitungan Harga Pokok Produk Time Driven Activity Based Costing}

Penghitungan harga pokok produk dilakukan dengan memperhitungkan kapasitas sumber daya. Fungsi produksi, kapasitas sumber daya adalah kos yang disediakan untuk menentukan konsumsi aktivitas yang terhitung. Aktivitas yang dapat dihitung adalah:

- Biaya Tenaga Kerja Langsung.

- Biaya overhead pabrik (BOP)

- Biaya Tenaga Kerja tidak Langsung.

- Biaya Listrik.

- Biaya penyusutan peralatan usaha. 
4.6 Alokasi Biaya Tenaga Kerja Langsung (selama satu bulan)

Kapasitas sumber tenaga kerja langsung adalah kapasitas yang disediakan oleh pelaku usaha sale pisang selama 1 bulan untuk membayar para pekerja yang membuat sale pisang. Kapasitas yang disediakan upah tenaga kerja langsung sebesar Rp. 5.000.00,- Tabel 4.8 menunjukkan kapasitas sumber daya tenaga kerja langsung yang dihasilkan dari perhitungan Time Driven Activity Based Costing (TDABC)

Tabel 4.8. Kapasitas Sumber Daya Tenaga Kerja Langsung

\begin{tabular}{c|c|c|c}
\multicolumn{1}{c}{ Aktivitas } & Jam Praktik / Hari & Jam Praktik / Bulan & $\begin{array}{c}\text { Biaya Tenaga Kerja } \\
\text { Langsung }\end{array}$ \\
\hline Sale Pisang Basah & $7,40 \mathrm{Jam}$ & $185,00 \mathrm{Jam}$ & Rp.1.665.000,- \\
\hline Sale Pisang Goreng & $4,60 \mathrm{Jam}$ & $151,25 \mathrm{Jam}$ & Rp.1.361.250.- \\
\hline Kapasitas Praktik & & $336,25 \mathrm{Jam}$ & \\
\hline Tenaga Kerja/Jam & Rp.9.000,- & & Rp.3.026.250,-- \\
\hline
\end{tabular}

Sumber: Data Primer

Tenaga Kerja $/$ Jam = Alokasi Sumber Daya $:$ Kapasitas Praktik

$$
\begin{aligned}
& =\text { Rp. } 5.000 .000,-\quad: 336,25 \mathrm{jam} \\
& =\text { Rp. } 15.000
\end{aligned}
$$

Berdasarkan perhitungan berbasis Time Driven Activity Based Costing (TDABC), alokasi per hari biaya tenaga kerja langsung untuk masing - masing varian produk :

- $\quad$ Sale pisang basah $\quad=$ Rp. 111.000

- Sale pisang goreng = Rp. 69.000

\subsection{Alokasi Biaya Tenaga Kerja tidak Langsung (selama satu bulan)}

Kapasitas sumber tenaga kerja tidak langsung adalah kapasitas yang disediakan oleh pelaku usaha sale pisang selama 1 bulan untuk membayar pengawas (mandor) produksi sale pisang. Kapasitas yang disediakan upah tenaga kerja tidak langsung sebesar Rp. 1.000.000,per bulan. Tabel 4.9 menunjukkan kapasitas sumber daya tenaga kerja tidak langsung yang dihasilkan dari perhitungan Time Driven Activity Based Costing (TDABC)

Tabel 4.9. Kapasitas Sumber Daya Tenaga Kerja tidak Langsung

\begin{tabular}{c|c|c|c} 
Aktivitas & Jam Praktik / Hari & Jam Praktik / Bulan & $\begin{array}{c}\text { Biaya Tenaga Kerja } \\
\text { tidak Langsung }\end{array}$ \\
Sale Pisang Basah & $7,20 \mathrm{Jam}$ & $180,00 \mathrm{Jam}$ & Rp.900.000,- \\
\hline Sale Pisang Goreng & 4,50 Jam & $112,50 \mathrm{Jam}$ & Rp.562.500,- \\
\hline Kapasitas Praktik & & $292,50 \mathrm{Jam}$ & \\
\hline Tenaga Kerja/Jam & Rp.5.000,- & & Rp.1.462.500 \\
\hline
\end{tabular}

Sumber: Data Primer 
Tenaga Kerja $/$ Jam = Alokasi Sumber Daya $:$ Kapasitas Praktik

$$
\begin{aligned}
& =\text { Rp. } 1.000 .000,-\quad: 292,50 \mathrm{jam} \\
& =\text { Rp. } 3.000
\end{aligned}
$$

Berdasarkan perhitungan berbasis Time Driven Activity Based Costing (TDABC), alokasi per hari biaya tenaga kerja tidak langsung untuk masing - masing varian produk :

- Sale pisang basah = Rp. 21.600

- Sale pisang goreng = Rp. 13.500

\subsection{Alokasi Sumber Daya Listrik}

Kapasitas sumber daya listrik usaha adalah kapasitas yang disediakan oleh pelaku usaha sale pisang selama satu bulan untuk membayar listrik. Kapasitas yang disediakan sebesar Rp. 15.000,-. Tabel 4.10 menunjukkan kapasitas sumber daya listrik yang dihasilkan dari perhitungan Time Driven Activity Based Costing (TDABC).

\begin{tabular}{|c|c|c|c|}
\hline Aktivitas & Jam Praktik / Hari & Jam Praktik / Bulan & $\begin{array}{c}\text { Biaya Tenaga Kerja } \\
\text { tidak Langsung }\end{array}$ \\
\hline Sale Pisang Basah & $2.10 \mathrm{Jam}$ & $52.50 \mathrm{Jam}$ & Rp.5.750,- \\
\hline Sale Pisang Goreng & 1 Jam & $25.00 \mathrm{Jam}$ & Rp.3.875,-- \\
\hline Kapasitas Praktik & & 77.50 Jam & \\
\hline Listrik/Jam & Rp.50,- & & Rp.9.625,- \\
\hline
\end{tabular}

Tabel 4.10. Kapasitas Sumber Daya Listrik

Sumber: Data Primer

$$
\begin{aligned}
\text { Listrik / Jam } & =\text { Alokasi Sumber Daya }: \text { Kapasitas Praktik } \\
& =\text { Rp. } 15.000,-\quad: 77.50 \text { jam } \\
& =\text { Rp. } 200,-
\end{aligned}
$$

Berdasarkan perhitungan berbasis Time Driven Activity Based Costing (TDABC), alokasi per hari biaya listrik untuk masing - masing varian produk :

$$
\begin{aligned}
& \text { - } \text { Sale pisang basah = Rp. 420.- } \\
& \text { - } \text { Sale pisang goreng= Rp. 200,- }
\end{aligned}
$$

\subsection{Alokasi Penyusutan (selama satu bulan)}

Aset tetap yang digunakan untuk memproduksi sale pisang seperti oven, wajan, dan alat pengemasan dikategorikan ke dalam peralatan usaha ditaksir Rp. 3.500 .000 dengan umur ekonomis 5 tahun dan metode penyusutan yang digunakan adalah garis lurus. Biaya penyusutan per tahun sebesar Rp. 700.000 (Rp. 3.500.000: 5 tahun), dan estimasi kapasitas per bulan Rp. 60.000. Tabel 4.11 menunjukkan kapasitas sumber daya penyusutan yang dihasilkan dari perhitungan Time Driven Activity Based Costing (TDABC) 
Tabel 4.11. Kapasitas Sumber Daya Penyusutan

\begin{tabular}{c|c|c|c}
\multicolumn{1}{c}{ Aktivitas } & Jam Praktik / Hari & Jam Praktik / Bulan & Penyusutan \\
Sale Pisang Basah & $1.50 \mathrm{Jam}$ & 37.50 Jam & Rp.11.250,- \\
\hline Sale Pisang Goreng & $1 \mathrm{Jam}$ & $25.00 \mathrm{Jam}$ & Rp.7.500,-- \\
\hline Kapasitas Praktik & & $\mathbf{6 2 . 5 0 ~ J a m}$ & Rp.18.750,- \\
\hline Biaya Penyusutan/Jam & Rp.300,-- & &
\end{tabular}

Penyusutan/jam = Kapasitas Sumber Daya Penyusutan : Kapasitas Praktik

Penyusutan/jam $=60.000: 62,50 \mathrm{Jam}$

Penyusutan/jam = Rp. 960

Alokasi penyusutan untuk masing-masing produk adalah:

- Sale pisang basah = Rp.1.400/ hari

- Sale pisang goreng = Rp. $960 /$ hari

\subsection{Perbedaan perhitungan biaya produk antara Metode Tradisional dan Metode TDABC}

Hasil perhitungan seluruh alokasi sumber daya yang dilakukan berdasarkan Time Driven Activity Based Costing (TDABC), peneliti dapat membandingkan hasil perhitunganya dengan metode tradisional, untuk mengetahui metode mana yang lebih tepat dan akurat, serta mampu untuk menekan biaya pada sale pisang basah, dan sale pisang goreng. Tabel 4.12 dan Tabel 4.12 menunjukkan perbedaan perhitungan metode tradisional dan TDABC berdasarkan varian sale pisang.

Tabel 4.12. Perhitungan Tradisional dan TDABC Varian Sale Pisang Basah

\begin{tabular}{|c|c|c|c|}
\hline & Tradisional & TDABC & Selisih \\
\hline & \multicolumn{3}{|c|}{ isang Basah } \\
\hline Penjualan & Rp.4.000.000,- & Rp.4.000.000,- & Rp. \\
\hline Biaya Produksi : & Rp.3.178.000,- & Rp.3.140.920,- & Rp. 37.080,- \\
\hline Biaya bahan Baku & Rp.2.500.000,- & Rp.2.500.000,- & Rp. \\
\hline Biaya Tenaga Kerja Langsung & Rp.150.000,- & Rp.111.000,- & Rp. 39.000,- \\
\hline Biaya Overhead & Rp.528.000,- & Rp.529.920,- & (Rp.1.920) \\
\hline Laba Kotor & Rp.822.000,- & Rp. 859.080,- & (Rp.37.080,-) \\
\hline Telepon & Rp.2.500,- & Rp.2.500,- & Rp. - \\
\hline Transportasi & Rp.50.000,-- & Rp.50.000,- & Rp. - \\
\hline Laba Bersih (Per Hari) & Rp.769.500,- & Rp.806.580,-- & (Rp. 37.080,-) \\
\hline Laba Bersih (Per Bulan / 25 hari) & Rp. 19.237.500,- & Rp. 20.164.500,- & (Rp. 927.000,-) \\
\hline
\end{tabular}

Sumber: Data Primer

Berdasarkan tabel 4.12, Sale pisang basah memiliki kos produksi berdasarkan metode tradisional sebesar Rp. 3.178.000,- sedangkan metode TDABC sebesar Rp. 3.140.920,-. Selisih kos produksi sebesar Rp. 37.080,-. Metode tradisional membebankan beban produksi lebih besar dibandingkan dengan metode TDABC, sehingga menyebabkan kos produk mengalami inefisiensi (pemborosan biaya), dan biaya mengalami distorsi. Jika dilihat item-item 
kos produksi, biaya tenaga kerja langsung metode TDABC lebih rendah dibandingkan dengan metode tradisional, hal ini dikarenakan beban dihitung berdasarkan waktu aktual (time driver) yang dihabiskan oleh tenaga kerja langsung dalam menghasilkan produk sale pisang basah. Metode TDABC menunjukkan bahwa Biaya Overhead Pabrik (BOP) lebih besar dibandingkan dengan metode tradisional. hal ini dikarenakan selain dihitung berdasarkan waktu aktivitas yang dihasilkan, terdapat penambahan beban penyusutan peralatan usaha yang tidak bebankan oleh metode tradisional. Metode tradisional menyebabkan penentuan kos produksi menjadi tidak tepat dan akurat dalam memberikan informasi pengambilan keputusan. Dampak dari perhitungan beban produksi yang lebih rendah berdasarkan TDABC, maka laba kotor sale pisang basah jauh lebih besar sebesar Rp. 37.080,- per hari.

Tabel 4.13. Perhitungan Tradisional dan TDABC Varian Sale Pisang Goreng

\begin{tabular}{|c|c|c|c|}
\hline & Tradisional & TDABC & Selisih \\
\hline & \multicolumn{3}{|c|}{ Sale Pisang Goreng } \\
\hline Penjualan & Rp. 440.000,- & Rp. 440.000,- & Rp. \\
\hline Biaya Produksi : & Rp. 352.500,- & Rp. 344.160,- & Rp.8.340,- \\
\hline Biaya bahan Baku & Rp. 200.000,- & Rp. 200.000,- & Rp. \\
\hline Biaya Tenaga Kerja Langsung & Rp. 70.000,- & Rp. 69.000,- & Rp. 1.000,- \\
\hline Biaya Overhead & Rp. 82.500,- & Rp. 75.160- & Rp. 7.340,- \\
\hline Laba Kotor & Rp. 87.500,- & Rp. 95.840,- & (Rp. 8.340,-) \\
\hline Telepon & Rp. 2.500,- & Rp. 2.500- & Rp. - \\
\hline Transportasi & Rp. 50.000,- & Rp. 50.000,- & Rp. - \\
\hline Laba Bersih (Per Hari) & Rp. 35.000,- & Rp. 43.340,-- & Rp. 8.340,-- \\
\hline Laba Bersih (Per Bulan / 25 hari) & Rp. 875.000,- & Rp. 1.083.500,- & Rp. 208.500,- \\
\hline
\end{tabular}

Berdasarkan tabel 4.13, Sale pisang goreng memiliki kos produksi berdasarkan metode tradisional sebesar Rp. 352.500,- sedangkan metode TDABC sebesar Rp. 344.160-. Selisih kos produksi sebesar Rp.8.340,-. Metode tradisional membebankan beban produksi lebih besar dibandingkan dengan metode TDABC, sehingga menyebabkan kos produk mengalami inefisiensi (pemborosan biaya), dan beban mengalami distorsi. Jika dilihat item-item kos produksi, beban tenaga kerja langsung metode TDABC lebih rendah dibandingkan dengan metode tradisional dengan selisih Rp. 1.000,-, dikarenakan beban dihitung berdasarkan waktu aktual (time driver) yang dihabiskan oleh tenaga kerja langsung dalam menghasilkan produk sale pisang basah. Metode TDABC menunjukkan bahwa BOP lebih besar dibandingkan dengan metode tradisional dengan selisih Rp. 7.340,- dikarenakan selain dihitung berdasarkan waktu aktivitas yang dihasilkan, terdapat penambahan beban penyusutan peralatan usaha yang tidak bebankan oleh metode tradisional. Metode tradisional menyebabkan penentuan kos produksi menjadi tidak tepat dan akurat dalam memberikan informasi pengambilan keputusan. Dampak 
dari perhitungan beban produksi yang lebih rendah berdasarkan TDABC, maka laba kotor sale pisang basah jauh lebih besar dengan selisih Rp. 8.340,- per hari.

\subsection{Model Penentuan Jual Sale Pisang dengan Metode TDABC}

Berdasarkan perhitungan harga pokok produksi dengan metode TDABC, pelaku usaha sale pisang dapat menentukan harga jual sale pisang dengan tepat dan kompetitif. Tabel 4.14 menunjukkan model yang tepat untuk menentukan harga jual sale pisang dengan metode TDABC.

Tabel 4.14. Harga Jual Sale Pisang dengan Metode TDABC

\begin{tabular}{l|l|l|l|l}
\multicolumn{1}{c|}{ Varian Sale } & \multicolumn{2}{c|}{ Sale Pisang Basah } & \multicolumn{2}{c}{ Sale Pisang Goreng } \\
& \multicolumn{1}{c}{ Tradisional } & \multicolumn{1}{c}{ TDABC } & \multicolumn{1}{c}{ Tradisional } & \multicolumn{1}{c}{ TDABC } \\
\hline Biaya produksi & Rp. 3.178.000,- & Rp. 3.140.920,- & Rp. 352.500,- & Rp. 344.160,- \\
\hline Unit produksi & 400 Unit & 400 Unit & 20 Unit & 20 Unit \\
\hline Harga unit per produk & Rp. 8.000,- & Rp. 7.800,- & Rp. 18.000,- & Rp.17.000,-- \\
\hline Mark up & $25 \%$ & $25 \%$ & $22 \%$ & $22 \%$ \\
\hline Harga jual & Rp. 10.000,-- & Rp. 9.750,-- & Rp. 22.000,- & Rp. 20.740,- \\
\hline Sumber: Data Primer & & & &
\end{tabular}

Berdasarkan tabel 4.14 metode tradisional menentukan harga jual berdasarkan harga pasar yaitu Rp.10.000,- untuk sale pisang basah, dan Rp. 22.000,- untuk sale pisang goreng. Harga per produk untuk sale pisang basah sebesar Rp. 8.000,- dan sale pisang goreng sebesar Rp. 18.000,-. Pelaku usaha sale pisang di Banyuwangi secara tidak langsung telah me-markup harga tiap masing-masing variab produknya yaitu sale pisang basah sebesar $25 \%$, dan sale pisang goreng $22 \%$.

Metode TDABC menunjukkan hasil yang berbeda dari biaya produksi sampai harga jual. Harga unit per produk untuk sale pisang basah sebesar Rp. 7.800,- dan sale pisang goreng sebesar. Rp. 18.000,-. Jika dijual mengikuti harga pasar metode TDABC dengan markup margin contribution sebesar $25 \%$ sale pisang basah, dan $22 \%$ sale pisang goreng, di peroleh harga jual sebesar Rp. 9.750,- sale pisang basah, dan Rp. 20.740,-. Perhitungan model TDABC dalam penentuan harga jual mampu memberi harga yang kompetitif dan dibawah harga pasar, sehingga berpeluang untuk memperoleh cost leadhersip dan profitabilitas yang tinggi. 


\subsection{Diskusi}

Peneliti membuktikan bahwa penentuan harga jual yang dilakukan oleh pengusaha sale pisang di Kabupaten Banyuwangi sebagian besar menggunakan harga pasar dengan mempertimbangkan perhitungan harga pokok produksi. Penerapan perhitungan harga pokok produksi menggunakan metode tradisional (kasar) ini tidak menggunakan catatan keuangan yang mengikuti standar akuntansi keuangan.

Pengusaha mengalami kesulitan dalam mengkalisifikasi biaya-biaya yang dimasukkan dalam perhitungan harga pokok produksi, seperti biaya langsung, biaya tenaga kerja langsung, dan biaya overhead. Mereka membebankan semua biaya pada biaya produksi, sehingga informasi biaya yang dihasilkan menjadi kurang tepat dan akurat untuk di jadikan dasar pengambilan keputusan bisnis. Kondisi ini terjadi karena minimnya pengetahuan atau ketidak pemahaman pengusaha sale dalam melakukan perhitungan biaya tepat dan akurat.

Temuan penelitian ini juga membuktikan bahwa perhitungan yang dilakukan pengusaha sale dengan metode tradisional (kasar) menggunakan 2 (dua) item pembebanan sumber daya tak langsung (indirect resources) pada satuan output. Metode tersebut membuat informasi biaya produksi sale pisang menjadi tidak akurat dan mengalami distorsi biaya. Distorsi informasi biaya terjadi karena penggunaan penggerak biaya (cost driver) berbasis volume (jam kerja, jumlah unit produk, dan lainnya) dalam membebankan sumber daya tak langsung dari cost pools ke satuan output. Banyaknya sumber daya tak langsung yang tidak digunakan secara proporsional, dengan satuan output yang dihasilkan. Karena alokasi berdasarkan volume, maka low-volume products cenderung undercosted, sementara high-volume products cenderung overcosted. Hal ini yang membuat para pengusaha sale pisang percaya bahwa high-volume products seharusnya memberikan margin contribution yang lebih tinggi dibandingkan lowvolume products karena lebih tingginya tingkat efisiensi akibat economies of scale. Cooper dan Kaplan (1991) menyatakan bahwa distorsi informasi biaya terjadi apabila biaya atau kuantittas yang dikonsumsi tidak dibebankan secara akurat pada pusat biaya atau produk.

Hasil penelitian ini mendukung hasil empiris Kaplan, dan Anderon (2007), Kaplan dan Porter, 2011, Stout, dan Joseph, 2011, Godil, et al., (2013), fatkhurrohman (2019), dan Azmi (2018) dan yang membuktikan bahwa Time Driven Activity Based Costing (TDABC) mampu memberikan solusi dalam mengalokasikan biaya ke produk lebih akurat dan efisien, karena adanya perkiraan waktu yang diperlukan untuk setiap aktivitas sebagai pemicu kos. Menghitung harga jual dengan menggunakan TDABC, pengusaha sale pisang dapat mengetahui kos produk dengan lebih akurat karena memasukkan item-item biaya langsung, dan tidak langsung. Item-item biaya seperti tenaga kerja langsung, tenaga kerja tidak langsung, dan biaya overhead pabrik di alokasikan berdasarkan penggunaan waktu sehingga dapat diketahui laba /rugi yang 
dihasilkan setiap varian produk dengan lebih akurat. Kondisi ini pada akhirnya dapat ditentukan harga jual yang lebih tepat untuk tiap varian produk yang tersedia.

Hasil penelitian ini juga mendukung hasil empiris dari Zohreh dan Samad (2011), Kuchta dan Troska (2007), Denovan et al, (2014), Naraswari, et al (2014), Higgins, et al (2014), dan Adeoti dan Valverde (2014) membuktikan bahwa penentuan harga jual dengan menggunakan metode Time Driven Activity Based Costing (TDABC), pemilik usaha dapat mengetahui kombinasi aktivitas apa saja yang memakan biaya besar, sehingga dapat melakukan pengelolaan biaya dengan baik dan perbaikan yang fokus pada proses, pelanggan, dan produk. Pengusaha sale menyadari dengan metode TDABC dapat melakukan pengelolaan biaya dan perbaikan proses dengan tepat, karena pengusaha sale dapat mengambil keputusan untuk memilih aktivitas-aktivtas dengan konsumsi sumber daya yang lebih efektif, sehingga mampu mengurangi seluruh biaya produksi secara signifikan. Metode ini, pengusaha sale dapat mengetahui cost to make and sell yang dapat menggambarkan seluruh sumber daya yang di korbankan untuk memproduksi produk, sehingga mampu mengetahui kos produk lebih tepat, dan menentukan harga jual yang lebih rasional dan kompetitif.

Mengetahui kondisi ini, pengusaha sale pisang seharusnya dapat melakukan evaluasi terhadap proses produksi untuk masing-masing varian. Seperti jumlah aktivitas, waktu yang dibutuhkan, jumlah karyawan yang mengerjakan setiap aktivitas. Jika pengusaha tetap menggunakan metode tradisional maka akan kehilangan efficiency costing dan berdampak pada penurunan kinerja keuangan usaha. Disisi lain, jika metode tradisional digunakan untuk jangka panjang, kinerja karyawan dapat menurun akibat mengalami tekanan dalam bekerja.

Membuat model perhitungan TDABC untuk pengusaha sale pisang di Kabupaten Banyuwangi, informasi yang dibutuhkan cukup sederhana yaitu informasi mengenai produk sale yang tersedia, jumlah karyawan dan jam kerja efektif, aktivitas-aktivitas dalam penyediaan produk sale pisang dan waktu yang dibutuhkan pada setiap aktivitas, dan seluruh biaya yang dikeluarkan. Informasi ini dapat diperoleh dengan cara observasi langsung dan wawancara mendalam. Penerapan TDABC dalam perhitungan harga jual sale pisang tidak membutuhkan biaya yang besar untuk memperoleh seluruh data tersebut dan menghitung sampai mendapatkan kos produk. Penerapan TDABC juga tidak membutuhkan waktu yang lama. Maka, perhitungan TDABC untuk menentukan harga jual pengusaha sale pisang di Kabupaten Banyuwangi sangat cocok dan lebih mudah diterapkan.

Peneliti menyadari keterbatasan informasi dalam menerapkan Time Driven Activity Based Costing (TDABC) merupakan kendala yang harus diselesaikan. TDABC memberikan peran penting dalam mengendalikan harga pasar. Kemudian peniliti mengadakan Forum Group Discussion (FGD) dengan kegiatan memberikan penjelasan mengenai cara dan manfaat 
menggunakan TDABC. Hasil FGD adalah menawarkan cara perhitungan produk menggunakan Time Driven Activity Based Costing (TDABC) peneliti memperoleh tanggapan positif dari pelaku usaha sale pisang yang telah mendapatkan penjelasan tentang sistem tersebut. Berikut beberapa kutipan percakapan dalam FGD:

"Jika kami menerapkan perhitungan harga jual dengan TDABC, maka kami dapat menjual dibawah harga pasar, dan otomatis produk kami jadi lebih banyak diminati konsumen serta harga menjadi lebih kompetitif" (FGD, 19 Agustus 2019)

"selisih biaya produksi dan laba bersih yang diperoleh antara metode tradisional dan TDABC adalah sedikit tapi cukup signifikan, tapi jika dihitung - hitung ya lumayan juga itu selisihnya. Bisa buat tambah modal kami kerja" (FGD 19 Agustus 2019)

"Perhitungan biayanya jadi lebih tepat, sangat rinci, detail dan akurat. Jadi kami menentukan harga jual bisa disesuaikan dengan biaya yang sebenarnya terjadi." (FGD 19 Agustus 2019)

"Kami setuju menggunakan metode TDABC dalam menentukan harga jual karena dasarnya perhitunganya sangat detail dan tepat" (FGD 19 Agustus 2019)

Metode Time Driven Activity Based Costing memungkinkan pembebanan biaya yang tinggi pada komponen produksi yang sering digunakan sesuai dengan aktivitas dan cost driver pada proses produksi. Selain itu juga dapat mengeliminasi komponen produksi yang tidak terpakai, hal ini memudahkan manajer (pemilik usaha) untuk mengambil keputusan yang berkaitan dengan keefektifan dan efisiensi sumber daya.

Time Driven Activity Based Costing (TDABC) sangat baik jika diterapkan pada usaha mikro, kecil maupun menengah. Selain dapat menghasilkan harga yang kompetitif, juga dapat melatih para UMKM dalam melakukan pencatatan transaksi usahanya. TDABC cocok diterapkan kepada UMKM binaan yang menjadi produk unggulan Banyuwangi dan berpotensi mengalami pertumbuhan ekonomi kreatif sesuai yang diharapkan pemerintahan Banyuwangi. Dampak jangka panjang dari pertumbuhan ekonomi kreatif adalah berkurangnya pengangguran, dan peningkatan pendapatan per kapita masyarakat Banyuwangi.

Pada prinsipnya metode TDABC dalam menentukan harga jual yang tepat sangat diinginkan oleh para pelaku usaha (UMKM) sale pisang, namun terdapat beberapa faktor yang membuat mereka kesulitan dalam mengimplementasikan metode ini yaitu :

1. Keterbatasan waktu

Dalam menerapkan perhitungan TDABC, pengusaha tidak memiliki waktu banyak karena posisi mereka bukan hanya sebagai pemilik, namun mereka juga merangkap sebagai pemasar, distributor, mandor, dan urusan pribadi lainnya. Sehingga pengawasan waktu perjam tidak dianggap efektif. 
Berikut pernyataan Bapak Nanang sebagai pemilik Sale Pisang Basah:

"Wah, kalau seperti ini saya belum bisa lakukan mbak, karna kan butuh proses pemahaman yang lama. Mungkin kalau saya sudah punya pegawai akuntan biar mereka saja yang menghitung. Karena saya masih juga merangkap sebagai distributor, ikut memasarkan produk juga walaupun nggak tiap hari sih. Belum lagi kegiatan seperti menjemput anak sekolah dan lain-lain, jadi mungkin saat ini saya masih belum bisa mempelajari dengan detil mbak" (Wawancara 11 Agustus 2019)

\section{Pengetahuan}

Rata-rata mereka adalah pengusaha yang memiliki background lulusan SMA/SMK sederajat dan sudah sukses mengembangkan bisnisnya, namun pengetahuan tentang TDBC bagi mereka adalah sesuatu yang asing.

"Waduuh, pusing saya mbak, menghitung hingga serinci itu, ya maklumlah mbak, pendidikan saya tidak sampai setinggi mbak, jadi tidak mengerti itu, harus banyak latihan dulu, agak lama lagi saya harus belajar metode yang kayak begini." (Wawancara 11 Agustus 2019)

3. Ketidakpastian cuaca

Salah satu pemilik usaha Sale Pisang Goreng mengatakan bahwa beliau tidak selalu melakukan produksi secara kontinyu setiap hari karena ketidakpastian cuaca. Seperti proses penjemuran yang menggantungkan cahaya matahari. Jika proses penjemuran belum selesai akibatnya aktivitas-aktivitas selanjutnya juga belum bisa dilakukan. Berikut pernyataan dari Bapak Andik sebagai salah satu pengusaha sale pisang basah:

" Ndak mesti mbak, kadang kalau cuacanya bagus, panas terus gitu, ya sehari bisalah untuk sekali produksi, tapi kalau cuacanya hujan terus ya kadang sehari itu bisa untuk aktivitas penjemuran saja. Jadi saya ndak bisa mematok biaya per jamnya mbak" (Wawancara 5 Agustus 2019)

\section{Kesimpulan, Keterbatasan, dan Saran}

Berdasarkan hasil dan pembahasan maka kesimpulan penelitian ini adalah Proses perhitungan biaya produk UMKM sale pisang di Kabupaten Banyuwangi belum menggunakan sistem akuntasi biaya yang baku, sehingga kos produk yang dihitung terlalu besar, dan penentuan harga jual berdasarkan pada harga pasar. Metode Time Driven Activity Based Costing (TDABC) mampu menekan biaya dan meningkatkan laba bersih masing-masing varian sale pisang. Metode TDABC sangat cocok diterapkan untuk pengusaha sale pisang karena lebih simple dan powerfull dan mampu mengalokasikan biaya secara akurat yang memudahkan pengusaha sale pisang mengalokasikan biaya sesuai aktivitas dan waktu yang digunakan dan berguna dalam penekanan harga. Hasil penelitian ini memiliki keterbatasan adalah sulitnya 
memperoleh informasi yang jelas mengenai pos-pos biaya yang dikeluarkan untuk menghitung kos produk dan harga jual. Peneliti selanjutnya diharapkan memilih obyek penelitian atau pelaku UMKM yang sudah melakukan pencatatan transaksi dengan baik. Sulitnya memperoleh responden yang merata dikarenakan tempat yang susah dijangkau dan keaktifan pengusaha sale pisang yang tidak ditemukan. Peneliti selanjutnya diharapkan untuk menentukan obyek penelitian atau pelaku UMKM didasarkan pada per wilayah seperti kecamatan, dan ukuran usaha.

\section{Daftar Pustaka}

Adeoti, A., A. dan Valverde, R. 2014. TDABC for the improvement of IT service operations. International Journal of Business and Management, 9 (1): 109-128.

Azmi, Z. 2018. Time Driven Activity Based Costing and Impelementation On Health Care Services. Jurnal Akuntansi dan Ekonomika, 8(1):75-84.

Dejnega, O. 2011. Method Time Driven Acitvity Based Costing - Literature Review. Journal of Applied Economic Sciences, 14 (2): 401-410.

Denovan, C., J., Hopkins, M., Kimmel, B., M., Koberna, S., dan Montie, C. A. 2014. How Cleveland Clinic used TDABC to improve value. Journal of Healthcare Financial Management, 68(6): 84-88.

Evaraet, P., dan Werner, B. 2007. Time-Driven Activity-Based Costing: Exploring the Underlying Model. Cost Management, 21(2):16-20.

Fatkhurrohman, A., M. 2019. Implementasi Time Driven Activity Based Costing dalam perhitungan biaya produksi UMKM Ngombe Cokelat. Jurnal Profita, 7(1): 1-11.

Gervaes, M., Yves, L., dan Charles., D. 2010. Time-Driven Activity-Based Costing (TDABC): An Initial Appraisal Through a Longitudinal Case Study. Journal of Applied Management Accounting Research, 8 (2): 1-20.

Godil, Danish, I., Shabibul, S., H., dan Yousuf, A,.2013. Application of Activity Based Costing in a Textile Company of Pakistan-A Case Study. Interdisciplinary Journal of Contemporary Research in Business, 4 (11): 602-625.

Hon, Jau-Shin dan Chu, Song-Jwu.2012. Implementation of Time-Driven Activity-Based Costing - A Case Study of Aerospace Precision Casting Factory. Proceedings of the Asia Pacific Industrial Engineering and Management System Conference, 22 (1): 426-435.

Hoozée, S., dan Bruggeman, W. 2010. Identifying Operational Improvements During the Design Process of a Time-driven ABC System: The Role of Collective Worker Participation and Leadership Style. Management Accounting Research, 21(3): 185-198.

Kaplan, R., S. dan Porter, M., E. 2011. How to Solve the Cost Crisis in Health Care. Harvard Business Review, 31(3); 46-64.

Kaplan, R.S., and Anderson, S., R. 2007. Time-Driven Activity-Based Costing. Harvard Business: School Press.

Kuchta, D., dan Troska, M. 2007. Activity Based Costing, and Customer Profitability. Cost Management Journal, 21(3): 18-25.

Namazi, M. 2016. Time-driven activity-based costing: Theory, applications and limitations. Iranian Journal of Management Studies (IJMS), 9(3): 457-482.

Naraswari, Francisca, V., A., dan Purwanugraha, H., A. 2014. Penerapan Time Driven Activity Based Costing dalam Perhitungan Biaya Instalasi Radiologi di Rumah Sakit Yakkum Purwodadi. Jurnal Ekonomi Akuntansi, 3 (1): 426-435. 
Soeherman, Bonnie. 2007. Time Driven Activity Based Costing: Penyederhanaan Kompleksitas Strategic Cost Management dalam Pencapaian Strategi. Akutansi dan Teknologi Informasi, 6(2): 108-120.

Stout, D., E., dan Joseph, M. Propri. 2011. Implementing Time Driven Activity Based Costing at a Medium-Sized Electronics Company. Management Accounting Quarterly, 12 (3): 1-11.

Tjahjadi, Bambang. 2010. Integrasi Time Driven Activity Based Costing (TDABC) dengan Enterprise Reources Planning (ERP): Generai Baru Sistem Manajemen Biaya Kelas Dunia. Majalah Ekonomi. Tahun XX. No.2.

Zohreh, H., dan Samad, S., A. 2011. Implementation of Time-Driven Activity-Based Costing System and Customer Profitability Analysis in The Hospitality Industry: Evidence from Iran. Economics and Finance Review, 1(8): 57-67. 